\title{
Spatial distribution and nesting behavior of the Black winged-stilt (Himantopus himantopus himantopus, Linnaeus 1758) in the urban wetland of Dakar Technopole (Senegal, West Africa)
}

\author{
Aissatou Yvette DIALLO ${ }^{1}$, Papa Ibnou NDIAYE ${ }^{1 *}$ et Saliou NDIAYE ${ }^{2}$ \\ ${ }^{1}$ Laboratoire de Biologie évolutive - Ecologie et gestion des écosystèmes, Département de Biologie animale, \\ Faculté des Sciences et Techniques, Université Cheikh Anta Diop de Dakar, Sénégal. \\ ${ }^{2}$ Ecole Nationale Supérieure d'Agriculture (ENSA), Université de Thiès, Sénégal. \\ "Corresponding author; E-mail: ibnou.ndiaye@ucad.edu.sn / Phone: (+221) 778142834
}

\section{ACKNOWLEDGMENTS}

The authors thank the Birdlife International who supported the study through a scholarship to AYD, used to carry out the fieldwork.

\begin{abstract}
Wetlands are important areas in the conservation of biodiversity and play a key role in the ecosystems regulation. Thus, considering that climate change effects combined with anthropogenic pressures on natural resources are causing loss of biodiversity in Sahelian countries such as Senegal, we need to do regular stock assessments. For this, we aimed at studying the Black winged-stilt (Himantopus himantopus himantopus) in the urban wetland of Technopôle in the Niayes of Dakar (capital of the republic of Senegal). Our study is focused on the spatial distribution and nesting of the Black winged-stilt (Himantopus himantopus himantopus) in Technopole, which is classified in the list of Important Bird Areas (IBAs) by Birlife International since 2001 under A4i criteria and is an important biodiversity hotspot. The Niayes of Dakar constitute a particular ecosystem of wetland, they play a determining role in the reproduction and the survival of manies birds' species. The nesting study was conducted from May to August 2012 and from May to August 2017. The maximum numbers of Black winged-stilt count during these periods are 531 individuals for 2012 and 766 individuals for 2017. However we highlight a decrease of the number of Black winged-stilt in the Technopole after the onset of the rains. Breeding data (25 nests in 2012 and 79 in 2017) show that this urban wetland is a preferred nesting site for Black winged-stilt. We report for the first time in this paper, so many Black wingedstilt nests in Senegal. Despite the disturbances related to anthropogenic factors, the breeding success of the Black winged-stilt reached $89.6 \%$ in May 2017. Thus, we believe that a strengthening of a conservation action plan of this site is urgent for a better preservation of the biodiversity, particularly the avian resources.
\end{abstract}

() 2019 International Formulae Group. All rights reserved

Keywords: Breeding, conservation, Himantopus himantopus, Niayes, water bird

\section{INTRODUCTION}

Water birds, most often migratory, fly very long distances during their annual migration cycles and follow "migration routes" linking their breeding sites to other areas important for their survival. They are a marvel of nature and a vital global resource for animal biodiversity. In the Important bird and biodiversity areas (IBAs) of the Niayes of Dakar. The few existing scientific studies have reported a significant presence of birds during a party of the year (Diallo, 2012; Diop, 
2012; Dione, 2014; Gadiaga, 2014). Breeding of Himantopus himantopus himantopus in Technopôle were reported for the first time by Diallo (2012). However, presence of $H . h$. himantopus in Senegal precisely in Saloum Delta National Park (PNDS) were reported in first by Morel, they are more than 20 years. $H$. $h$. himantopus lives mainly near freshwater and salt marshes, in saltlick, shallow lakes, coastal lagoons, flooded fields and rice paddies. In this paper, we contribute to the production of data about this species in Senegal, particularly in the urban wetland of Technopôle (in Dakar, the capital of Senegal). These data are about the distribution and reproduction of the Black winged-stilt, $H$. $h$. himantopus. According to Birdlife International (2016), $H$. himantopus is represented by four subspecies: $H . h$. himantopus, $H$. h. knudseni, $H$. h. melanurus and $H$. h. leucocephalus. The subspecies $H$. $h$. himantopus is made up of six groups that are the following:

- Group 1: himantopus, West and South-West Europe, West Africa

- Group 2: himantopus, Central and East Europe, East Mediterranean

- Group 3: himantopus, South-West Asia

- Group 4: himantopus, Sub-Saharan Africa

- $\quad$ Group 5 : himantopus, Meridionalis

- Group 6 : himantopus, madagascar. Only groups 1 and 4 concern Senegal. Group 1 is estimated between 71,000 and 82,000 individuals and group 4 is estimated between 100,000 and 200,000 individuals. The world population is estimated between 450,000 to 780,000 individuals. The species breeds generally in shallow freshwaters and brackish wetlands with substrates of sand, mud or clay and open margins, islets or spits from the nearby water level. The nesting period is between April and June. Female lays four olive-green eggs stained with gray and black. The incubation is biparental and lasts 22 to 26 days. At birth, the chicks are covered with dark down, with gray spots or blackish brown. The lower parts are white. This juvenile plumage is preserved until the ninth month. The chicks are nesting and leave the nest to hide in the surrounding vegetation. They are fed by both parents. They fly away after four weeks after birth and become independent two to four weeks later (Rihane, 2007; Adamou et al., 2009; Birdlife International, 2016). The main objective of this study is to confirm the presence of Black winged-stilt in the Niayes of Pikine and provide the first scientific data on its reproduction in this site.

\section{MATERIALS AND METHODS Location of the study area}

The Niayes system stretches along the main Senegalese coast to the heart of the Cape Verde peninsula. The Niayes consist of interdune depressions where the touch of the water table is conducive to the development of a Guinean-type climate. It is a market garden, arboreal and poultry area of the first plan that supplies the agglomerations of Dakar and surrounding areas. In the Dakar region, many of the areas formerly occupied by the Niayes (Figure 1a) have now disappeared because of the strong demographic pressure. The breeding data of Himantopus himantopus presented in this document come from the urban wetland named Technopole (geographical coordinates $14^{\circ} 45^{\prime} 16.69^{\prime \prime} \mathrm{N}$ and $17^{\circ} 24^{\prime} 48.41^{\prime \prime} \mathrm{W}$; Figure $1 \mathrm{~b}$ ), which is part of the Niayes of Dakar (the Niayes of Pikine or Technopole, the catchment area, the Mbeubeuss lake, the Retba lake, the Mbaouane lake and the Pink Lake or Tanma lake). Technopole superficie is about 200 hectares. It is bordered to the north by the Golf-Nord district of Guediawaye, to the south by the highway, to the east by the Pikine agglomeration and to the west by Camberene.

The Technopole project on the Niayes site was authorized by the Senegalese State by Law No. 96-36 of December $31^{\text {st }}$, 1996. The aim was to host research and teaching centers as well as companies developing technological innovation. Thus, a protective wall had been erected on the side of the highway.

\section{Physical aspect and biological resource of the study area}

The Niayes of Pikine belong to the sub-Canarian microclimate. Its climate is influenced by the maritime trade winds which are present all the year. These trade winds mitigate seasonal thermal contrasts and soften 
temperatures (Touré, 2004). Annual rainfall is generally between 300 and $500 \mathrm{~mm}$ and their average reaches $469 \mathrm{~mm}$. Maxims are recorded in August. The very short rainy season usually lasts three to four months. Annual temperatures vary between $24.5^{\circ} \mathrm{C}$. The warmest month of the year is October, with an average temperature of $28.1{ }^{\circ} \mathrm{C}$ and February is the coldest month with an average temperature of $21.7^{\circ} \mathrm{C}$ (Ndiaye et al., 2012). Vegetation is dominated by a typical Guinean species, Elaeis guineensis, which marks the contact zone between the bottom of the dune system and the depression. We also note the presence of Cocos nucifera and a large herbaceous layer conditioned by the topography of the environment (Touré, 2004).

These Niayes interdunal depressions are home to species with subguineous affinity (10\%) such as Detarium senegalense, Kigelia africana, Antiaris africana, Malacantha aulnifolia, and Sudanian (12\%) Parkia biglobosa, Prosopis africana.

In this vegetation cover lives a very diverse fauna, consisting of reptiles and soil organisms (protozoa, nematodes, rotifers, earthworms, ants, and other small apterygota insects) that constitute a large part of the bird's food. The latter represent the majority of vertebrate present on the science park and have about 150 species (Hopkins and Diop, 2011). Some water bodies, invaded by reeds, are rich in fish that are represented by three species (Tilapia guineensis, Tilapia sp, Clarias anguillaris) (A.Y. Diallo unpublished data).

\section{Fieldwork}

At the beginning of the fieldwork, we carried out preliminary surveys and prospecting at the Niayes level in Dakar. These surveys and prospecting enabled us to identify the Technopôle as a reproduction site for the Black Winged-stilt and track nesting behavior.

\section{Spatial distribution}

This part of the work was carried out from May $28^{\text {th }}$ to August $27^{\text {th }} 2012$ and from May $2^{\text {nd }}$ to August $29^{\text {th }} 2017$. For this, we divided the surveyed area into several zones indicated in the Figure 2. Thus we made a systematic count of all the Black Winged-stilts between 07:00 $\mathrm{hr}$ and 12:00 $\mathrm{hr}$ in each zone. This allowed us to locate the geographical distribution of Black Winged-stilts in the Technopôle. Data on the geographical distribution of Black Winged-stilts were analyzed using ArcGIS 10.3 and R-3.3.3 software.

\section{Nesting behavior}

We identified the nests of Black Winged-stilt simultaneously to the study of the spatial distribution of these birds. The main objective of the protocol was to monitor the reproduction of the Black winged-stilt population in the Niayes of Pikine, thus making it possible to specify the life cycle of the species (laying dates, number of eggs laid, dates of hatching and incubation time). Thus, we carried out a regular check of the nests and their states of evolution. The parameters of whether or not the nest is occupied by the male or the female as well as the stage of reproduction (during laying or incubation) are recorded.

\section{Statistical analysis}

Data on nesting behavior of Black winged-stilt was analyzed using ArcGIS 10.3 and R-3.3.3 software. We also used the Kendall rate to measure the relationships between the measured quantities (nests / chicks), and Fisher's exact test (or then Chisquare test) to show that the changes in size between the different zones are significant or not. And, finally we use the statistical hypothesis test (T-test) to evaluate relationship between the presence of the Black Winged-stilts and the water level.

The Mayfield method described by the relationship below allowed us to estimate the probability of survival (daily) of nests and / or young chicks, an indicator of reproductive success.

$p=\frac{(a-b)}{a} \quad\{p=$ daily survival probability $/ a$

$=$ exposure days $/ \quad b=$ failed nests $\}$

$P=p^{x} \quad\{P=$ survival probability $/ \mathrm{x}=$ nesting period\} 


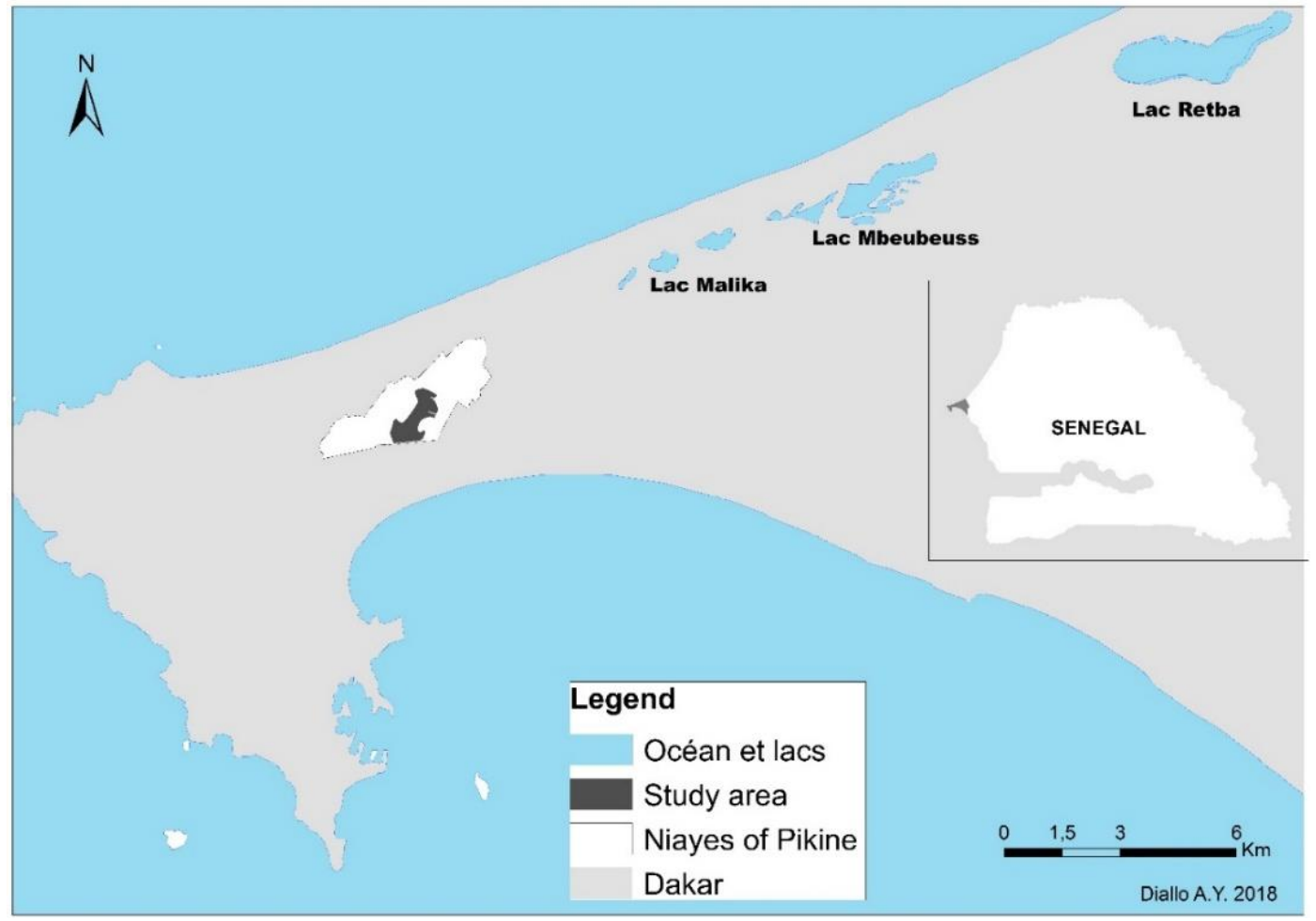

Figure 1a: Location of the Niayes of Dakar.

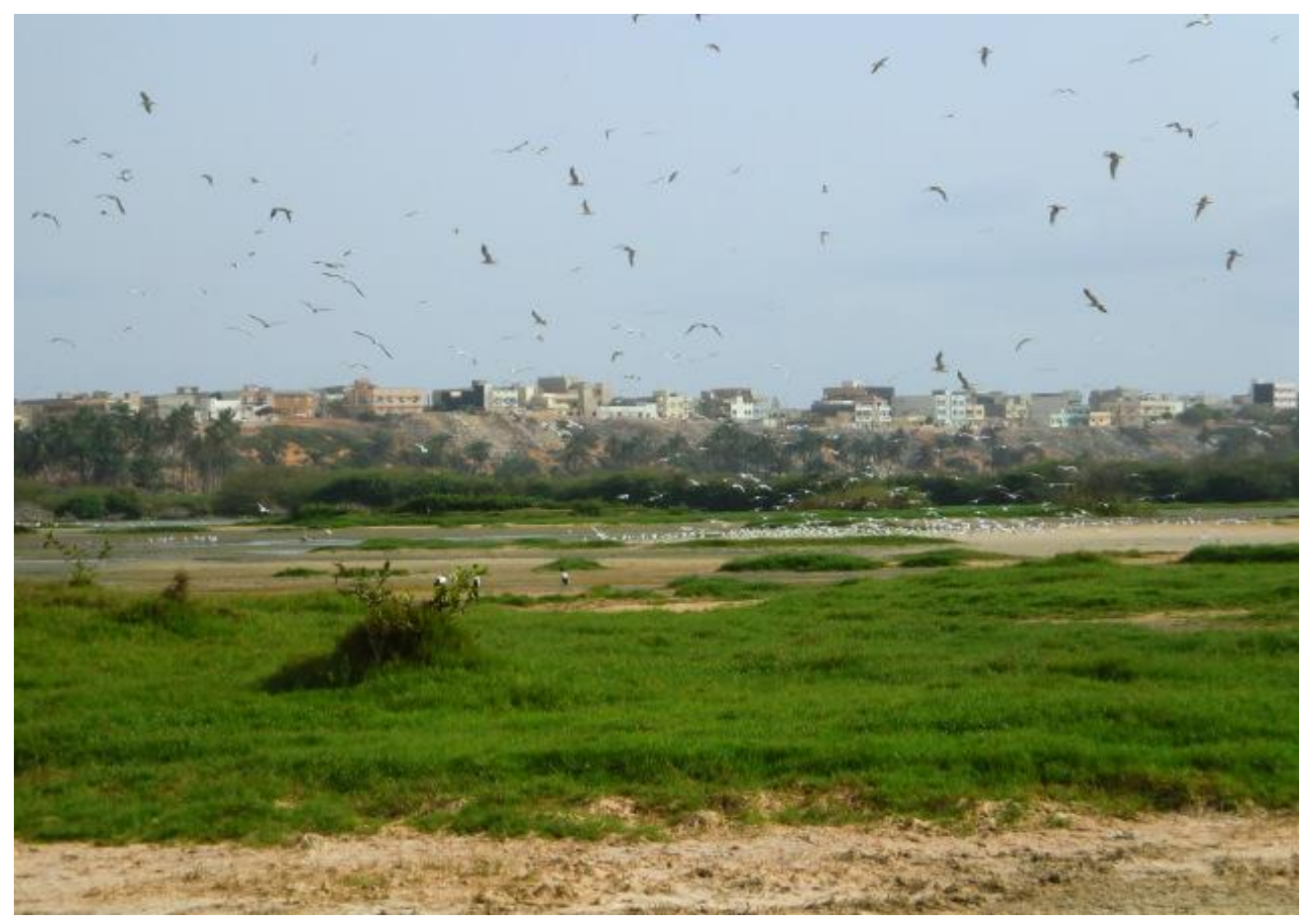

Figure 1b: A view of Technopole. 


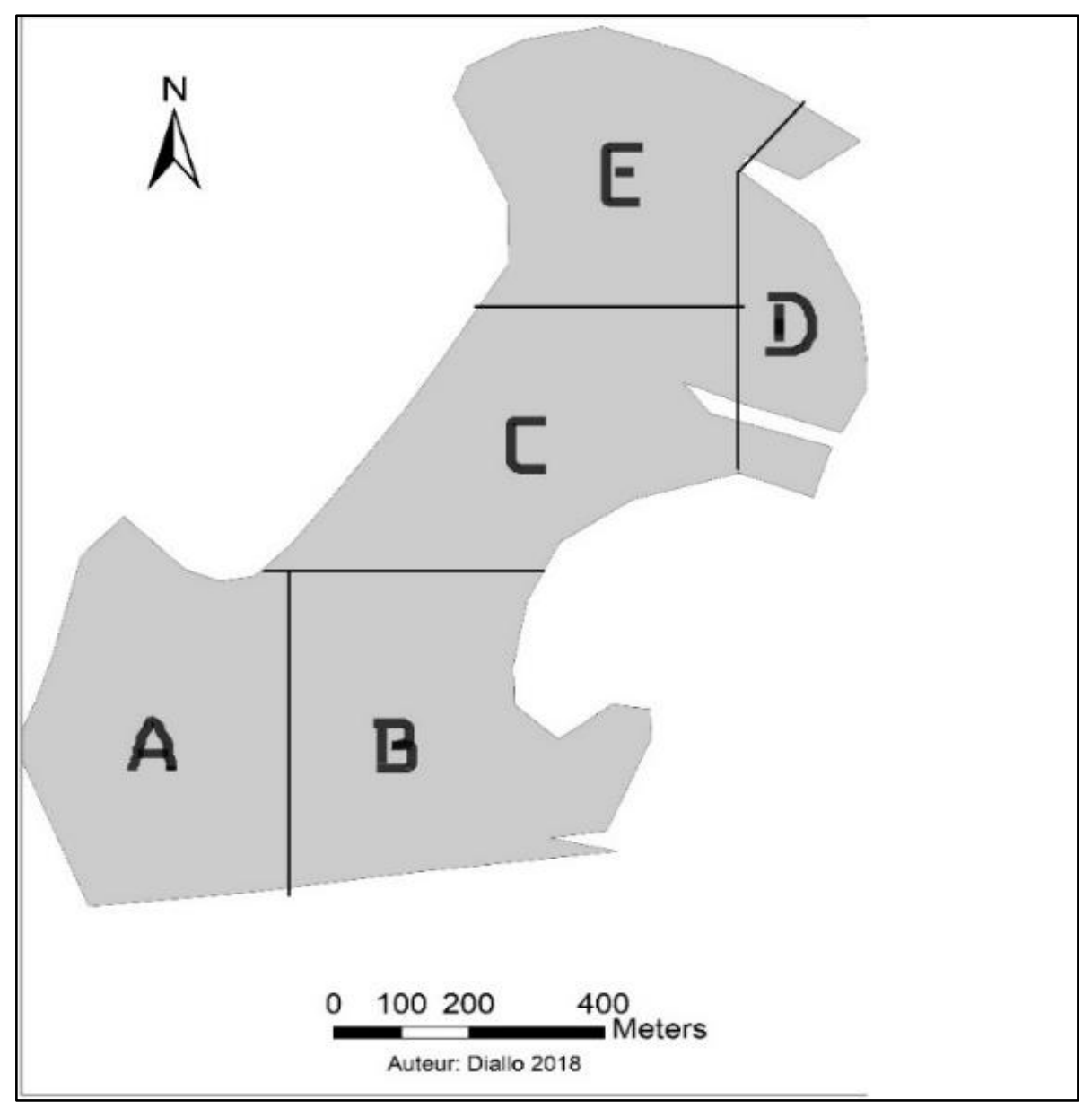

Figure 2: Subdivisions in the study area.

\section{RESULTS}

\section{Evolution of the workforceI}

In 2012, the population of Black winged-stilt in Technopole increase and reach a maximun number of 407 invidious in Jun during the weeks 1 to 4 of the study (Figure 3a). In 2017, we have two maxima: 766 individious in May and 714 in July (Figure $3 b)$.

\section{Spatial distribution}

There are some changes in the relative abundance of birds. The numbers are higher in zones A, C and E. The Fisher's exact test allowed us to show that the variation of the numbers between zones $\mathrm{A}, \mathrm{C}$ and $\mathrm{E}$ is not significant $(\mathrm{P}$-value $=0.55$ for intervals $95 \%$ confidence). So, the favorite places for Black winged-stilts in the Technopole are in zones $\mathrm{A}, \mathrm{C}$ and $\mathrm{E}$.

In 2017 the numbers are higher in zones $\mathrm{B}, \mathrm{C}$ and $\mathrm{E}$. The variation in the numbers of birds between these zones is significant (the $\mathrm{P}$-value $\left(2.2 \mathrm{e}^{-16}\right)$ is below the significance threshold of 0.05 . Fisher's exact test also leads to a rejection of the null hypothesis $\left(\mathrm{H}_{0}\right.$ : the two qualitative variables are independent)). These results show that the spatial distribution of white stilts at the Technopole varied well between 2012 and 2017. It was only in zones A and B that small changes in the distribution of birds were noted (Figures $4 \mathrm{a}$ and $4 \mathrm{~b}$ ). May be, this fact is due to a collapse of the dyke during 2014, causing an increase of the water level. The consequence is a massive departure of the birds species. 


\section{Nesting behavior}

A total of seventy-nine (79) nests of Black winged-stilts were identified and monitored in 2017, but only fifty-five (55) could be geolocated (Table 1). The other twenty-four (24) were located in inaccessible places (indicated in grey circle on the map (Figure 5).

The geographical distribution of these nests at the site is shown in Figure 6 . Throughout the site, breeding occurs only in the southern part of the Technopole where there is less anthropic pressure. At the Technopole the white stilt nests observed are either on rocks in the water (Figure 6 (a)) or on the grass (Figures 6 (e) and (f)).

The homogeneity of the nest distribution (Figure 7) is tested by Chi-square test the test based on the same total number of nests per area. The distribution is not homogeneous according to the Chi-square test (Chi-square $=73.6$, P-value $<0.001)$. The nests are concentrated in zones $\mathrm{B}$ and $\mathrm{C}$ (respectively five and nineteen nests). The number of nests begins to fall with the arrival of wintering. At the same time, we are seeing an increase in hatching. We think that this result is due the fact that in 2012, environmental conditions in zone $\mathrm{B}$ and $\mathrm{C}$ are favorable for nesting in these area and anthropogenic activities are almost absents. But, during 2017 we assist to a development of fishing activities and a predation of bird eggs by wandering dogs.

The maximum nest built and early hatching are noted at the beginning of breeding during the month of May (Figure 8). According to Mayfield's method, the probability of survival $\mathrm{P}=0.896$, so survival has a success of $89.60 \%$ in the first week. And by the fourteenth week of breeding, it is $53.10 \%$ with $\mathrm{P}=0.531$. Also, with the advanced wintering and rising water levels in the site, survival is almost zero.

Figure 9 allows us to determine the percentage of well-hatched nests during the breeding season. After the determination of the average of all the nests, half is suitably brooded during the breeding season. This parameter is decisive for the success of the reproduction because it makes it possible to determine the quality of the nesting.

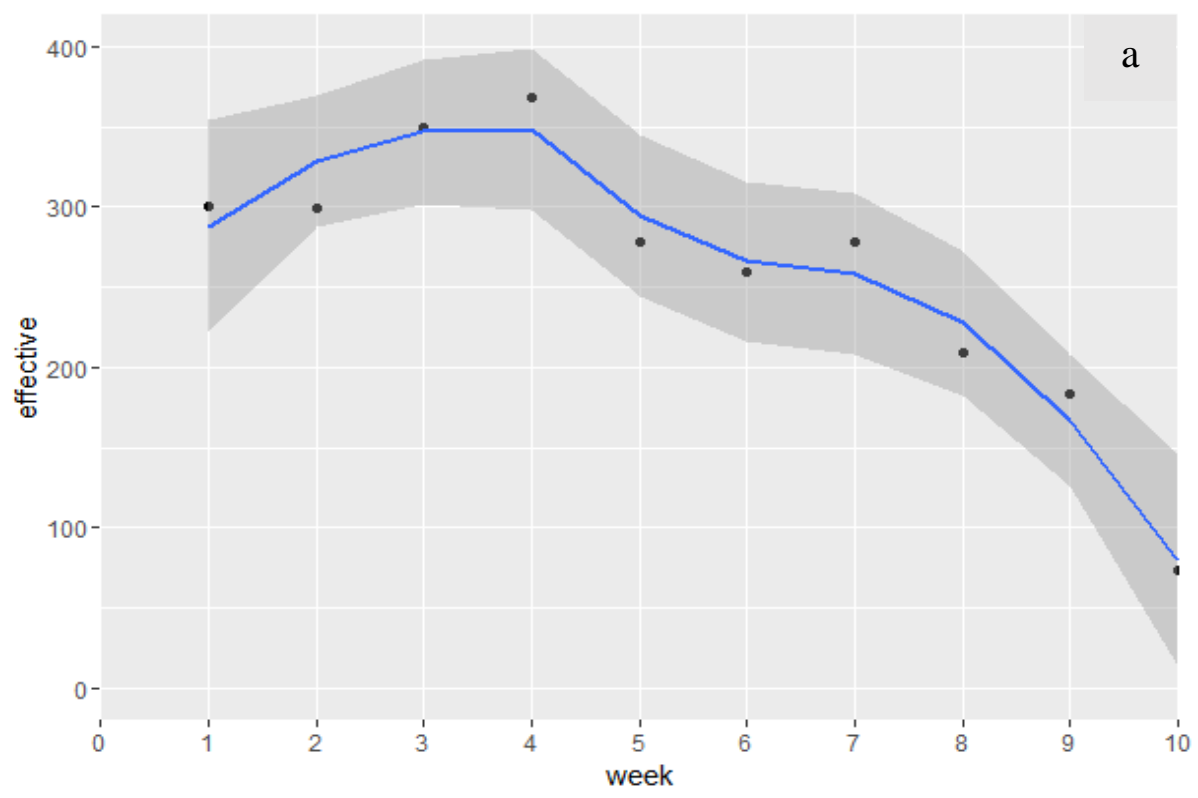




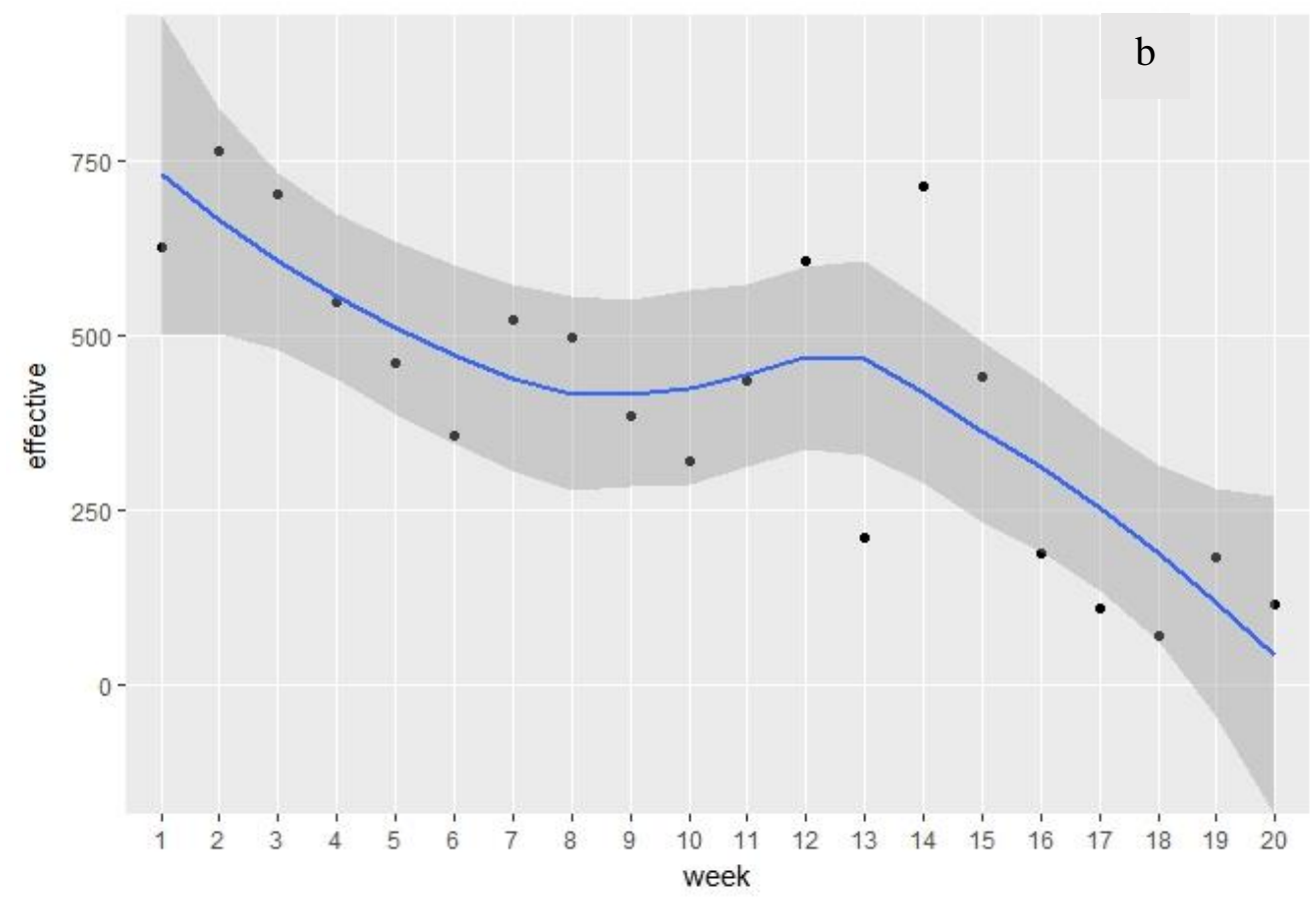

Figure 3: Evolution of the numbers of Black winged-stilts at the Technopole. a) From May to August 2012 and b) from May to September 2017.
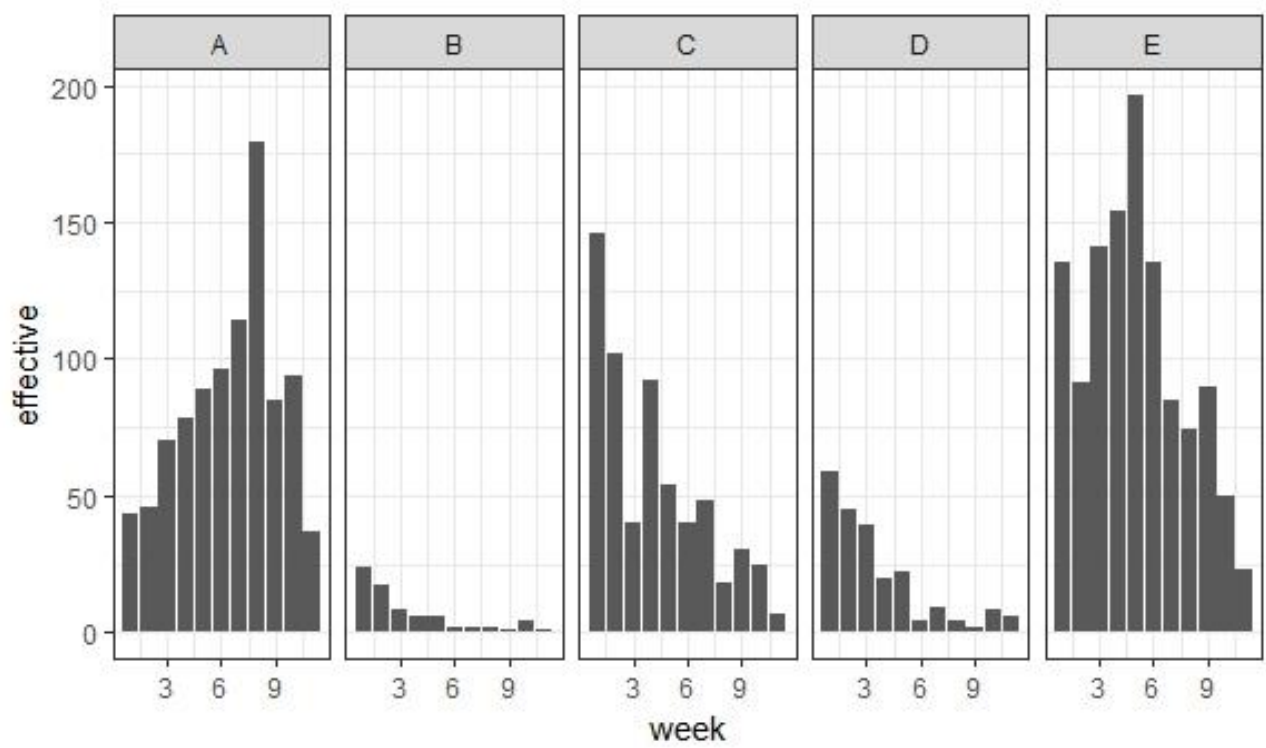

Figure 4a: Spatial distribution of Black Winged-Stilt at the Technopole: from May to August 2012. 


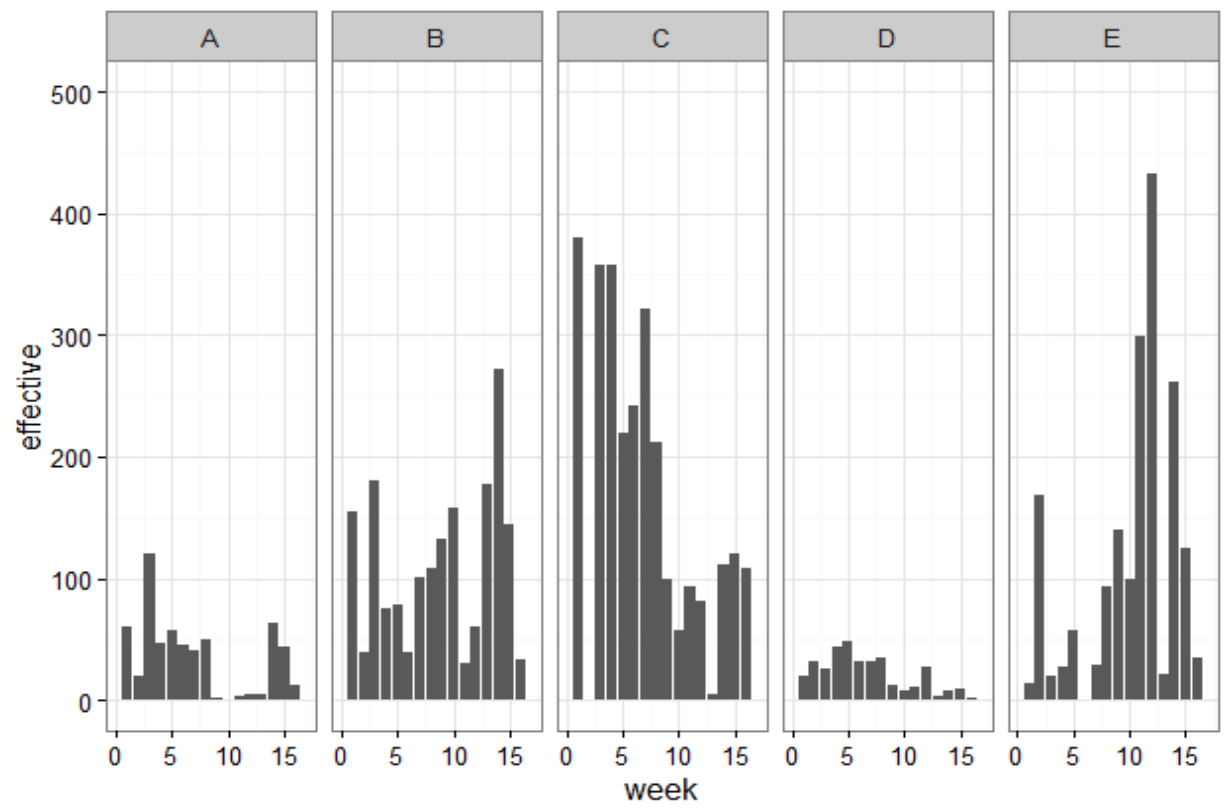

Figure 4b: Spatial distribution of Black Winged-Stilt at the Technopole: May to September 2017.

Table 1: Geographical coordinates of Black winged-stilt nests reported at Technopole.

\begin{tabular}{|c|c|c|c|c|c|}
\hline $\begin{array}{c}\text { Nest } \\
\text { number }\end{array}$ & Latitude & Longitude & $\begin{array}{c}\text { Nest } \\
\text { number }\end{array}$ & Latitude & Longitude \\
\hline 1 & $14^{\circ} 33^{\prime} 56,796^{\prime \prime} \mathrm{N}$ & $17^{\circ} 26^{\prime} 19,659^{\prime \prime} \mathrm{W}$ & 29 & $14^{\circ} 44^{\prime} 51,381 " \mathrm{~N}$ & $17^{\circ} 25^{\prime} 3,824^{\prime \prime} \mathrm{W}$ \\
\hline 2 & $14^{\circ} 44^{\prime} 50,745^{\prime \prime} \mathrm{N}$ & $17^{\circ} 25^{\prime} 8,596 " \mathrm{~W}$ & 30 & $14^{\circ} 44^{\prime} 51,381 " \mathrm{~N}$ & $17^{\circ} 25^{\prime} 3,791 " \mathrm{~W}$ \\
\hline 3 & $14^{\circ} 44^{\prime} 51,206^{\prime \prime} \mathrm{N}$ & $17^{\circ} 25^{\prime} 8,134^{\prime \prime} \mathrm{W}$ & 31 & $14^{\circ} 44^{\prime} 51,478^{\prime \prime} \mathrm{N}$ & $17^{\circ} 25^{\prime} 3,825^{\prime \prime} \mathrm{W}$ \\
\hline 4 & $14^{\circ} 44^{\prime} 51,271^{\prime \prime} \mathrm{N}$ & $17^{\circ} 25^{\prime} 8,067^{\prime \prime} \mathrm{W}$ & 32 & $14^{\circ} 44^{\prime} 51,577 " \mathrm{~N}$ & $17^{\circ} 25^{\prime} 3,726^{\prime \prime} \mathrm{W}$ \\
\hline 5 & $14^{\circ} 44^{\prime} 51,272^{\prime \prime} \mathrm{N}$ & $17^{\circ} 25^{\prime} 8,034^{\prime \prime} \mathrm{W}$ & 33 & $14^{\circ} 44^{\prime} 51,528^{\prime \prime} \mathrm{N}$ & $17^{\circ} 25^{\prime} 3,689^{\prime \prime} \mathrm{W}$ \\
\hline 6 & $14^{\circ} 44^{\prime} 51,24^{\prime \prime} \mathrm{N}$ & $17^{\circ} 25^{\prime} 7,967^{\prime \prime} \mathrm{W}$ & 34 & $14^{\circ} 44^{\prime} 51,253^{\prime \prime} \mathrm{N}$ & $17^{\circ} 25^{\prime} 3,589^{\prime \prime} \mathrm{W}$ \\
\hline 7 & $14^{\circ} 44^{\prime} 51,046 " \mathrm{~N}$ & $17^{\circ} 25^{\prime} 7,864^{\prime \prime} \mathrm{W}$ & 35 & $14^{\circ} 44^{\prime} 51,285^{\prime \prime} \mathrm{N}$ & $17^{\circ} 25^{\prime} 3,656^{\prime \prime} \mathrm{W}$ \\
\hline 8 & $14^{\circ} 44^{\prime} 50,98^{\prime \prime} \mathrm{N}$ & $17^{\circ} 25^{\prime} 7,897^{\prime \prime} \mathrm{W}$ & 36 & $14^{\circ} 44^{\prime} 51,155^{\prime \prime} \mathrm{N}$ & $17^{\circ} 25^{\prime} 3,688^{\prime \prime} \mathrm{W}$ \\
\hline 9 & $14^{\circ} 44^{\prime} 50,784^{\prime \prime} \mathrm{N}$ & $17^{\circ} 25^{\prime} 8,062^{\prime \prime} \mathrm{W}$ & 37 & $14^{\circ} 44^{\prime} 51,122^{\prime \prime} \mathrm{N}$ & $17^{\circ} 25^{\prime} 3,688^{\prime \prime} \mathrm{W}$ \\
\hline 10 & $14^{\circ} 44^{\prime} 50,555^{\prime \prime} \mathrm{N}$ & $17^{\circ} 25^{\prime} 8,193 " \mathrm{~W}$ & 38 & $14^{\circ} 44^{\prime} 50,96^{\prime \prime} \mathrm{N}$ & $17^{\circ} 25^{\prime} 3,619^{\prime \prime} \mathrm{W}$ \\
\hline 11 & $14^{\circ} 44^{\prime} 51,083^{\prime \prime} \mathrm{N}$ & $17^{\circ} 25^{\prime} 4,356^{\prime \prime} \mathrm{W}$ & 39 & $14^{\circ} 44^{\prime} 51,024 " \mathrm{~N}$ & $17^{\circ} 25^{\prime} 3,72^{\prime \prime} \mathrm{W}$ \\
\hline 12 & $14^{\circ} 44^{\prime} 51,083^{\prime \prime} \mathrm{N}$ & $17^{\circ} 25^{\prime} 4,289^{\prime \prime} \mathrm{W}$ & 40 & $14^{\circ} 44^{\prime} 51,056^{\prime \prime} \mathrm{N}$ & $17^{\circ} 25^{\prime} 3,787^{\prime \prime} \mathrm{W}$ \\
\hline 13 & $14^{\circ} 44^{\prime} 51,116^{\prime \prime} \mathrm{N}$ & $17^{\circ} 25^{\prime} 4,289^{\prime \prime} \mathrm{W}$ & 41 & $14^{\circ} 44^{\prime} 50,991 " \mathrm{~N}$ & $17^{\circ} 25^{\prime} 3,786^{\prime \prime} \mathrm{W}$ \\
\hline 14 & $14^{\circ} 44^{\prime} 51,149^{\prime \prime} \mathrm{N}$ & $17^{\circ} 25^{\prime} 4,256^{\prime \prime} \mathrm{W}$ & 42 & $14^{\circ} 44^{\prime} 51,088^{\prime \prime} \mathrm{N}$ & $17^{\circ} 25^{\prime} 3,854^{\prime \prime} \mathrm{W}$ \\
\hline 15 & $14^{\circ} 44^{\prime} 51,181 " \mathrm{~N}$ & $17^{\circ} 25^{\prime} 4,29^{\prime \prime} \mathrm{W}$ & 43 & $14^{\circ} 44^{\prime} 50,018^{\prime \prime} \mathrm{N}$ & $17^{\circ} 25^{\prime} 3,508^{\prime \prime} \mathrm{W}$ \\
\hline 16 & $14^{\circ} 44^{\prime} 51,214^{\prime \prime} \mathrm{N}$ & $17^{\circ} 25^{\prime} 4,257^{\prime \prime} \mathrm{W}$ & 44 & $14^{\circ} 44^{\prime} 50,153 " \mathrm{~N}$ & $17^{\circ} 25^{\prime} 3,042^{\prime \prime} \mathrm{W}$ \\
\hline 17 & $14^{\circ} 44^{\prime} 51,214^{\prime \prime} \mathrm{N}$ & $17^{\circ} 25^{\prime} 4,223^{\prime \prime} \mathrm{W}$ & 45 & $14^{\circ} 44^{\prime} 50,415^{\prime \prime} \mathrm{N}$ & $17^{\circ} 25^{\prime} 2,878^{\prime \prime} \mathrm{W}$ \\
\hline 18 & $14^{\circ} 44^{\prime} 51,247^{\prime \prime} \mathrm{N}$ & $17^{\circ} 25^{\prime} 4,19^{\prime \prime} \mathrm{W}$ & 46 & $14^{\circ} 44^{\prime} 50,257^{\prime \prime} \mathrm{N}$ & $17^{\circ} 25^{\prime} 2,408^{\prime \prime} \mathrm{W}$ \\
\hline 19 & $14^{\circ} 44^{\prime} 51,312^{\prime \prime} \mathrm{N}$ & $17^{\circ} 25^{\prime} 4,191 " \mathrm{~W}$ & 47 & $14^{\circ} 44^{\prime} 51,831 " \mathrm{~N}$ & $17^{\circ} 25^{\prime} 4,297^{\prime \prime} \mathrm{W}$ \\
\hline
\end{tabular}




\begin{tabular}{|c|c|c|c|c|c|}
\hline 20 & $14^{\circ} 44^{\prime} 51,377^{\prime \prime} \mathrm{N}$ & $17^{\circ} 25^{\prime} 4,225^{\prime \prime} \mathrm{W}$ & 48 & $14^{\circ} 44^{\prime} 52,225^{\prime \prime} \mathrm{N}$ & $17^{\circ} 25^{\prime} 3,967^{\prime \prime} \mathrm{W}$ \\
\hline 21 & $14^{\circ} 44^{\prime} 51,409^{\prime \prime} \mathrm{N}$ & $17^{\circ} 25^{\prime} 4225, " \mathrm{~W}$ & 49 & $14^{\circ} 44^{\prime} 52,357^{\prime \prime} \mathrm{N}$ & $17^{\circ} 25^{\prime} 3,801 " \mathrm{~W}$ \\
\hline 22 & $14^{\circ} 44^{\prime} 51,475^{\prime \prime} \mathrm{N}$ & $17^{\circ} 25^{\prime} 4,193^{\prime \prime} \mathrm{W}$ & 50 & $14^{\circ} 44^{\prime} 52,483 " \mathrm{~N}$ & $17^{\circ} 25^{\prime} 4,171^{\prime \prime} \mathrm{W}$ \\
\hline 23 & $14^{\circ} 44^{\prime} 51,54^{\prime \prime} \mathrm{N}$ & $17^{\circ} 25^{\prime} 4,16^{\prime \prime} \mathrm{W}$ & 51 & $14^{\circ} 44^{\prime} 52,848^{\prime \prime} \mathrm{N}$ & $17^{\circ} 25^{\prime} 6,547^{\prime \prime} \mathrm{W}$ \\
\hline 24 & $14^{\circ} 44^{\prime} 51,605^{\prime \prime} \mathrm{N}$ & $17^{\circ} 25^{\prime} 4,161 " \mathrm{~W}$ & 52 & $14^{\circ} 44^{\prime} 52,227^{\prime \prime} \mathrm{N}$ & $17^{\circ} 25^{\prime} 6,908^{\prime \prime} \mathrm{W}$ \\
\hline 25 & $14^{\circ} 44^{\prime} 51,67^{\prime \prime} \mathrm{N}$ & $17^{\circ} 25^{\prime} 4,128^{\prime \prime} \mathrm{W}$ & 53 & $14^{\circ} 44^{\prime} 50,009^{\prime \prime} \mathrm{N}$ & $17^{\circ} 25^{\prime} 7,519^{\prime \prime} \mathrm{W}$ \\
\hline 26 & $14^{\circ} 44^{\prime} 51,541 " \mathrm{~N}$ & $17^{\circ} 25^{\prime} 4,06^{\prime \prime} \mathrm{W}$ & 54 & $14^{\circ} 44^{\prime} 55,926^{\prime \prime} \mathrm{N}$ & $17^{\circ} 25^{\prime} 49,035^{\prime \prime} \mathrm{W}$ \\
\hline 27 & $14^{\circ} 44^{\prime} 51,541 " \mathrm{~N}$ & $17^{\circ} 25^{\prime} 4,06^{\prime \prime} \mathrm{W}$ & 55 & $14^{\circ} 44^{\prime} 56,664 " \mathrm{~N}$ & $17^{\circ} 25^{\prime} 53,121^{\prime \prime} \mathrm{W}$ \\
\hline 28 & $14^{\circ} 44^{\prime} 51,444^{\prime \prime} \mathrm{N}$ & $17^{\circ} 25^{\prime} 3,959 " \mathrm{~W}$ & & & \\
\hline
\end{tabular}
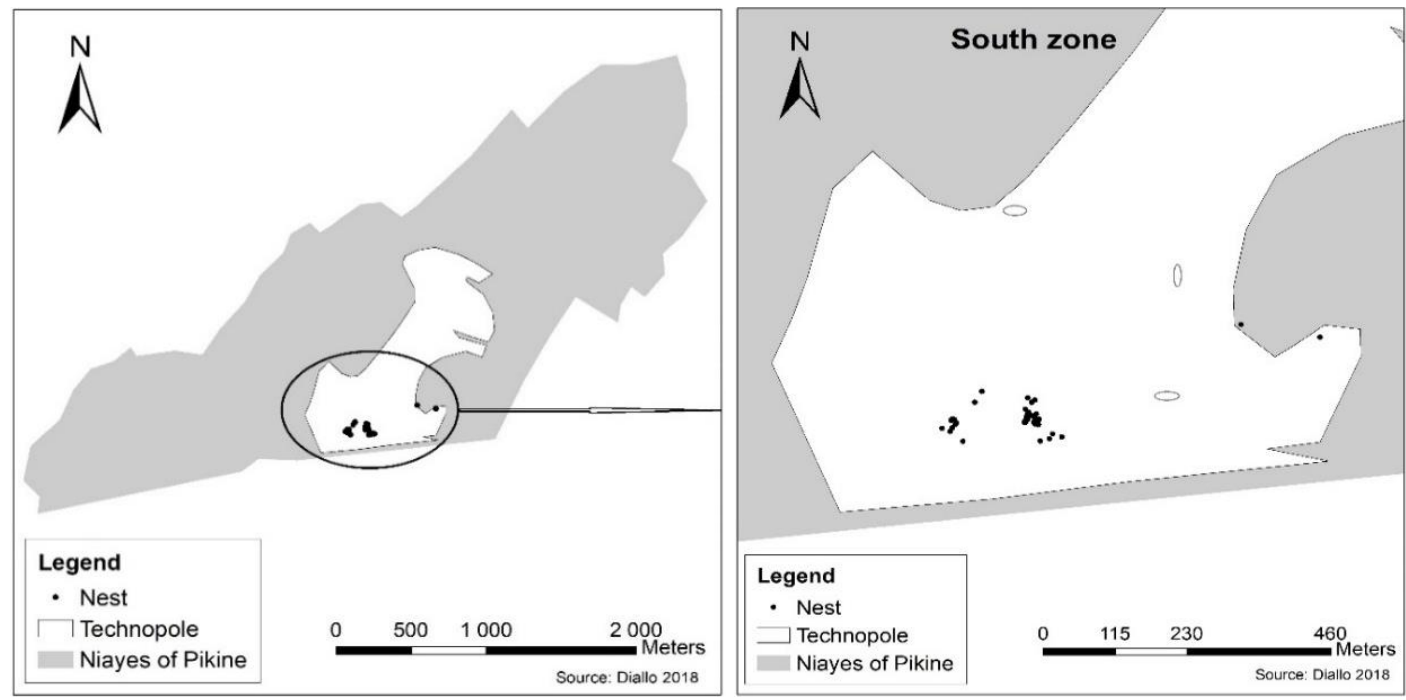

Figure 5: Nest distribution at the Technopole in 2017

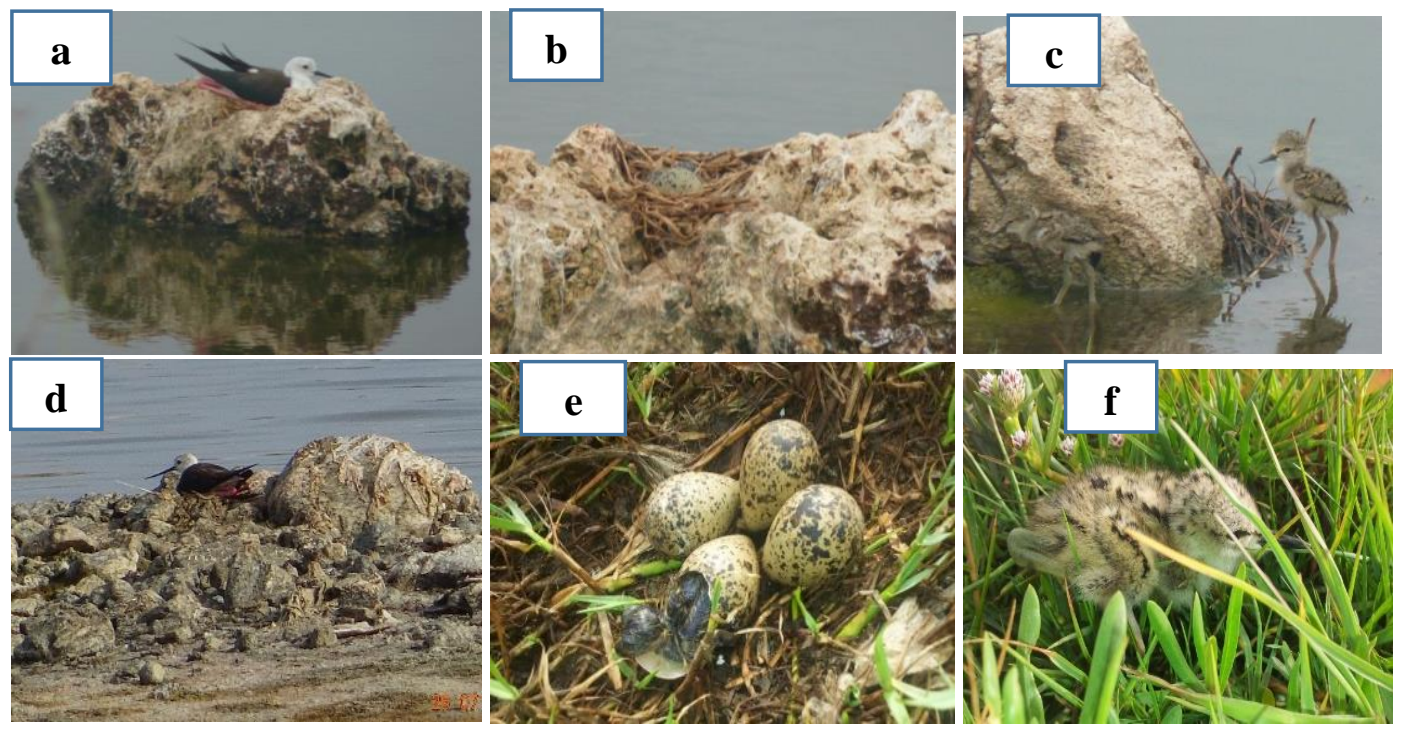

Figure 6: Black winged-stilt breeding.

Pictures taken July 2012: a) incubation, b) eggs, c) two chicks Pictures taken July 2017: d) incubation, e) eggs, f) one chick 


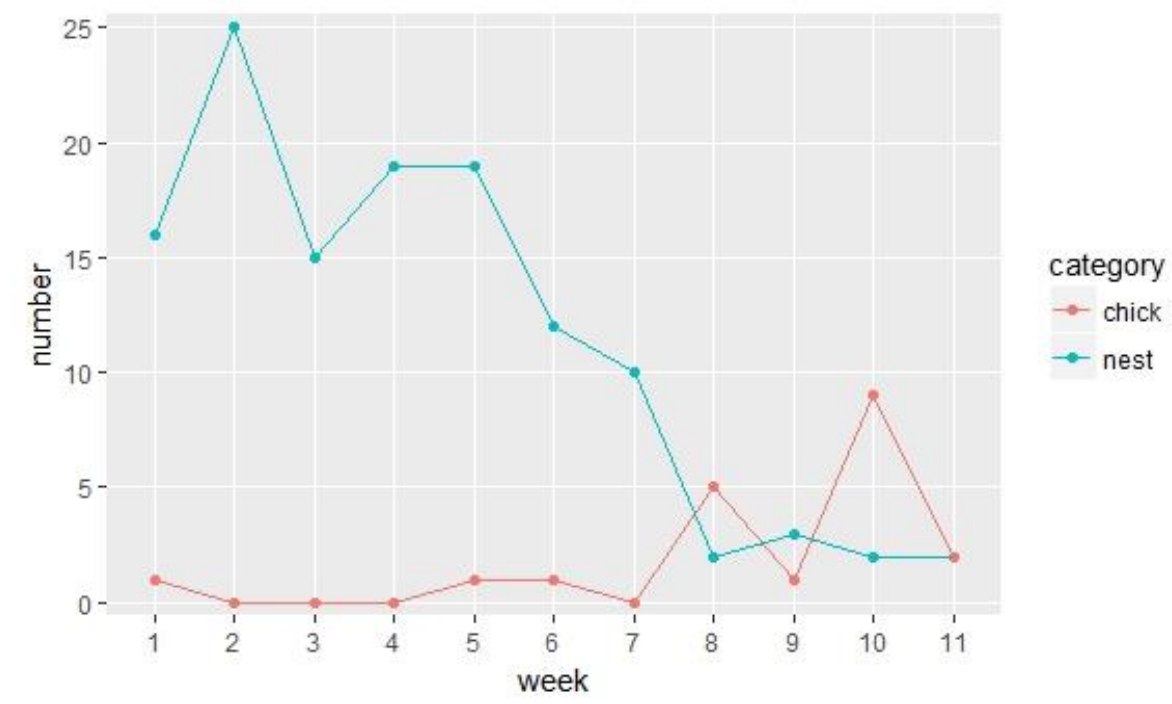

Figure 7: Evolution of the number of nests and chicks for the year 2012.

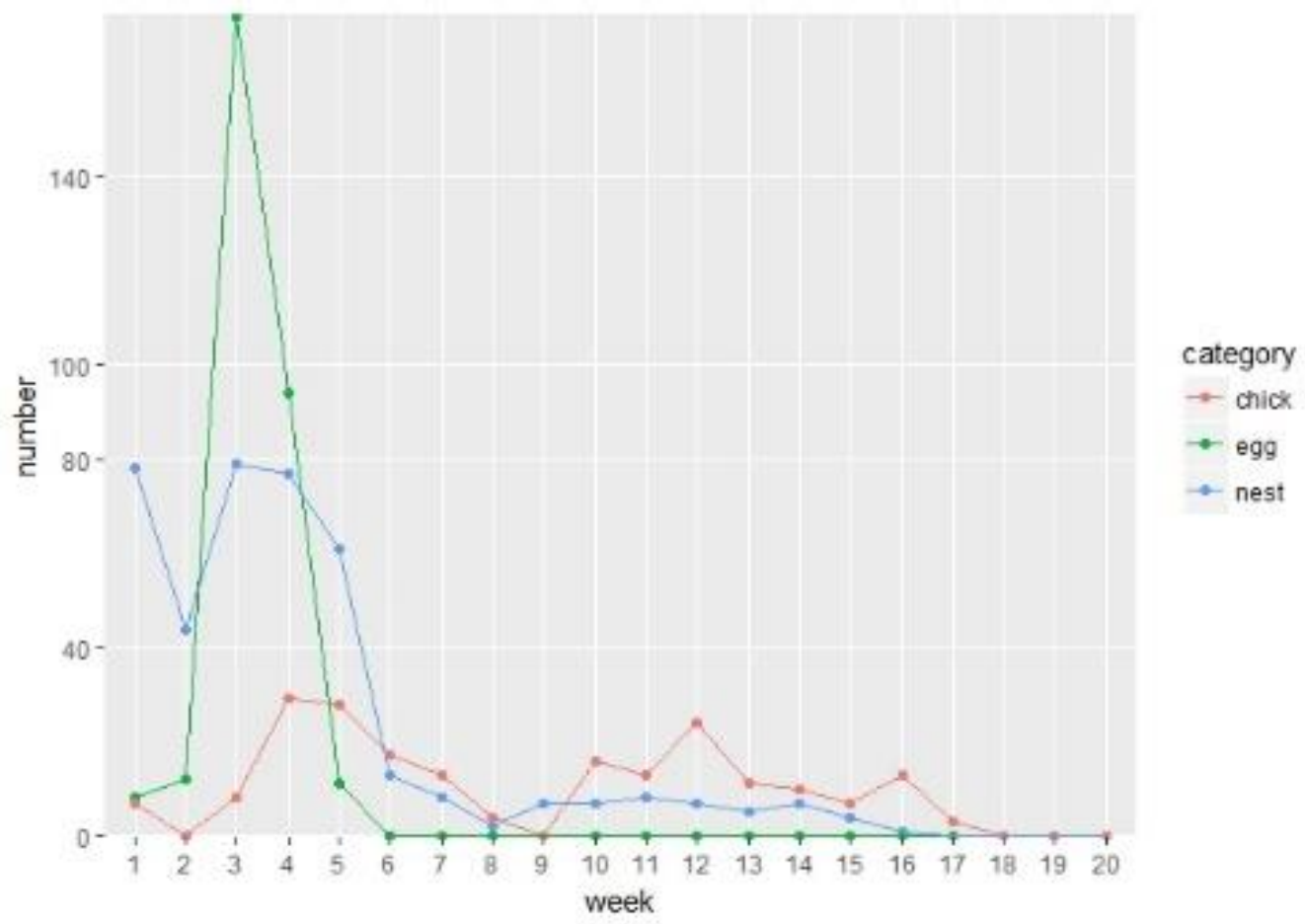

Figure 8: Evolution of the number of nests, eggs and chicks for the year 2017. 


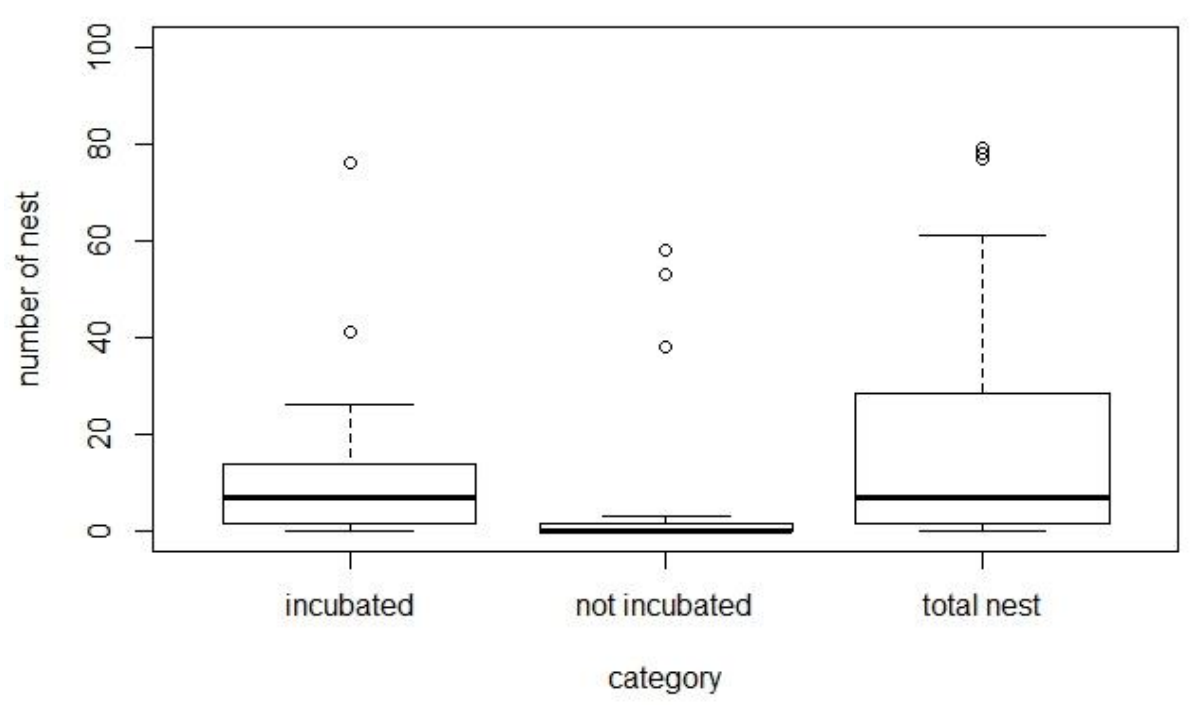

Figure 9: Average number of nests by category in 2017.

\section{DISCUSSION}

The decline of the white stilt population in the study area as soon as the rains begin is explained by the fact that these species prefer to live in shallow water bodies. According to $\mathrm{Yu}$ and Swennen (2004), these species generally evolve to a depth of between 6 and 21 centimeters. Also, changes in water levels affect the abundance of wading birds and their feeding behavior. (Maheswaran et al., 2001).

At the Technopole, sewage and runoff from surrounding areas are dumped, significantly raising the water level. This caused in 2012 the early departure of these birds from the site; hence we can formulate the hypothesis that: Birds could stay in the Technopole all year round if spilled water was limited and during rainy season only rainwater was collected.

This hypothesis was confirmed in 2017 because well after the breeding season, the Black winged-stilt population remained on the site. This is corroborated by the results of the latest counts in 2018, in which 1226 individuals composed of adults and Black winged-stilt juveniles are recorded (National Parks Directorate / International Waterbird Census, 2018). However, this decrease in the abundance of Black winged-stilts could also have another explanation: an increase in the number of wetlands during wintering, thus favoring the dispersal of birds.

The study on the spatial distribution of the white stilts is also an essential step for the understanding of the demoecological processes. The statistical analysis of the numbers makes it possible to determine this distribution of individuals in space and time. There are several types of distribution. For our study we have a more or less irregular distribution of individuals. In 2012 zones A, C and $\mathrm{E}$ were the most occupied by individuals and nests are more concentrated in zones B and C. On the other hand, there is a slight change in 2017 when individuals occupy zones $\mathrm{B}, \mathrm{C}$ and $\mathrm{E}$ and nests are more concentrated in zone A. This proves that this change is punctuated by the dynamics of other individuals that do not reproduce yet, because the individuals able to reproduce choose places less frequented by the rest of the colony and more conducive to the smooth development of nesting.

The few existing information on the Black winged-stilt in Senegal are reported more than 25 years ago by Baillon and Sylla with observations of two nests on the bird island of Saloum Delta National Park, one nest in Retba lake, one nest in Tataguine, one nest in Sine Saloum and eight nests on the shores of Malika lake. The nest of the Black 
winged-stilt is a shallow depression scraped into the ground. It is usually located on a pile of vegetation, in water on aquatic weeds, or near water on the shore (Birdlife International, 2016). However, on the site of Technopole we observed nests on rocks or on piles of stones.

Nest density and position within the same colony can influence the hatching success and survival of the young. Lagarde (2013) study showed the spatial and temporal distribution of nest establishment within a colony. Younger birds, being ready to breed later in the season, would be pushed back to the periphery of the colony by older, more experienced individuals that nest in the center.

The species nests in small colonies ranging from two to fifty pairs, and the pairs formed vigorously defend their nests and their territory (Birdlife International, 2016). However, in this study, almost twice the colony was observed over a staggered period because the majority of the nests are recorded in early May (that is, at the beginning of breeding).

Many studies indicate that early hatching has a significantly better hatching success than late hatching (Toral and Figuerola, 2012).

The nesting period is generally between April and June, but in the case of our study, it continued until the end of August. This may be due to the decrease in rainfall in the Dakar region, so that the problems of submersion of nests have not been posed. Also, some inexperienced latecomers did not start in time their reproduction. Lagarde (2013) has found that it is often young, less experienced birds that are found in the late period.

We were able to count twenty-five nests in 2012, and this number is tripled in 2017 when we had seventy-nine nests. This is a real contribution to the knowledge of the reproduction of this species in Senegal.

The breeding biology of Black Winged-stilt begins to be better known, thanks to studies conducted by various authors: Arroyo, 2000; Cuervo, 2003, 2004, 2005; Alexander et al., 2011, Issiaka et al., 2018.

Our results show that nesting success as measured by nest survival can differ between weeks and decrease significantly with the progression of the season. And throughout the follow-up, we noted that half of the nests were properly hatched, which proved to be a great success despite the predation on eggs by stray dogs (Figure 10). These stray dogs live in the Technopole site and breed there.

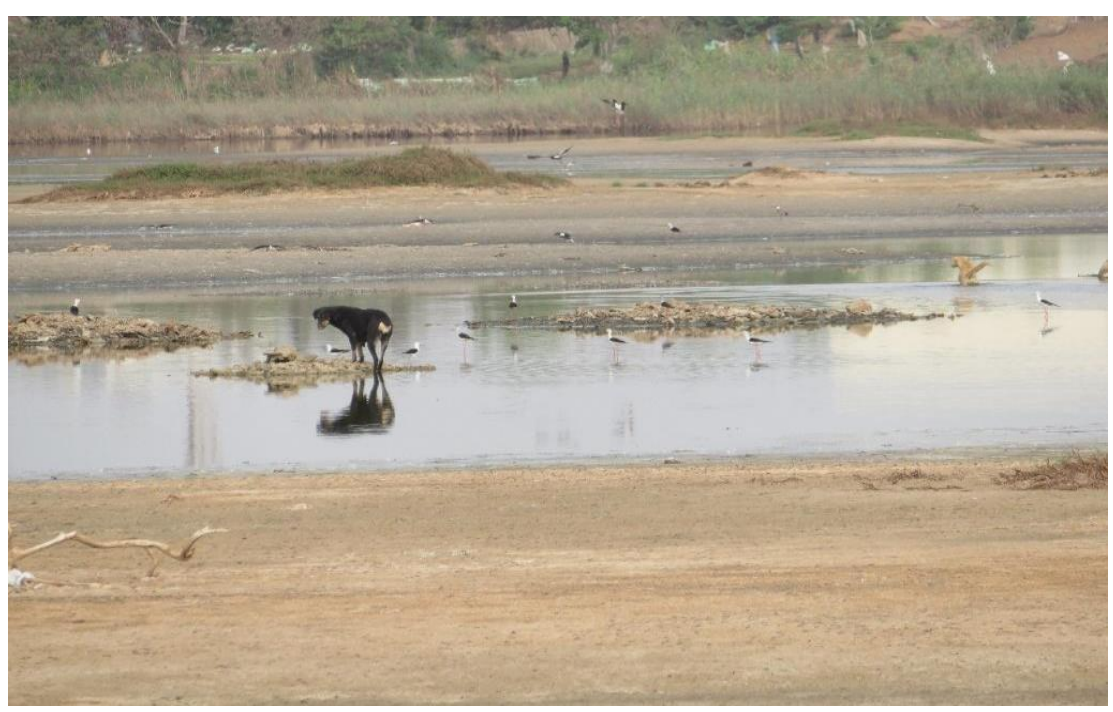

Figure 10: Image of a stray dog in Technopole, a predator of birds'eggs. 


\section{Conclusion}

The Niayes of Pikine shelter a diversified avian fauna during most of the year despite its status of unprotected wetland. We observed the behavior of birds before and during wintering, especially the white stilt that breeds there. Thus, we have observed and understood how the resources of the environment are selected and exploited by this species. The findings from the exploitation of the results show a fairly regular attendance of Black winged-stilts in the Niayes of Pikine. The nesting of the Black winged-stilt at Technopole is described for the first time in our study. In addition, during this study, we found a greater number of Black winged-stilt nests throughout Senegal. These data will contribute to the knowledge of the reproduction of the Black winged-stilt in Senegal. However, efforts still need to be made in the context of the protection and conservation of the site because anthropization is more and more recurrent, and to this is added the actions of stray domestic animals such as dogs that are becoming more and more uncontrollable.

\section{COMPETING INTERESTS}

The authors declare that they have no competing interests.

\section{AUTHORS'CONTRIBUTIONS}

AYD was mentored by PIN and SN for doing the field work and all the authors participated in the data analysis and the manuscript writing.

\section{ACKNOWLEDGMENTS}

The authors thank the association Nature - Communautés - Developpement (NCD) for material support, The Parcs Nationaux and Aires Marines Communautaires directions for permited studies in their sites and to all those who contributed to the work on the ground, especially to Mr. Diallo B. and local populations.

\section{REFERENCES}

Adamou AE, Kouidri M, Chabi Y, Skwarska J, Bańbura J. 2009. Egg size variation and breeding characteristics of the
Black-winged Stilt Himantopus himantopus in a Saharan oasis. Acta Ornithol, 44: 1-7. DOI: https://doi.org/10.3161/000164509X464 821

Alexander KL, Sebastian-Gonzalez E, Botella F, Sanchez-Zapata JA.2011. Occupancy patterns of irrigation ponds by blackwinged stilts Himantopus himantopus. Ardeola, 58(1) : 175-182. DOI: 10.13157/arla.58.1.2011.175.

Aourir M, Qninba A. 2015. Nidification de l'Échasse blanche Himantopus himantopus (Linnaeus 1758) sur l'Oued Noun-Assaka (sud-ouest du Maroc). GoSouth Bulletin, 12 : 78-83.

Ashoori A. 2011. Breeding Ecology of the Black-winged Stilt Himantopus himantopus in Boujagh National Park, Gilan Province, Northern Iran. Prodoces, 6(1) : 87-91.

Barati A, Etezadifar F, Sharikabad VN. 2012. Contrasting reproductive ecology of Black-winged Stilt Himantopus himantopus at two colonies in Wertern Iran. Wader Study Group Bulletin, 119(2): 120-124.

Barbosa A. 2002. Does vigilance always covary negatively with group size? Effects of foraging strategy. Acta Ethologica, 5: 51-55. DOI: 10.1007/s10211-002-0059-0

Biondi M, Pietrelli L, Ortenzi D, Cecchtti S, Mocci A. 2008. Nuove riproduzioni di cavaliere d'italia Himantopus himantopus nel lazio (2008). Alula, XV(1-1): 123-128.

Birdlife International. 2016. Himantopus himantopus. The IUCN Red List of Threatened Species 2016: e.T22727969A86541570. DOI: http://dx.doi.org/10.2305/IUCN.UK.201 6-3.RLTS.T22727969A86541570.en. Downloaded on 01 March 2019.

Chandler RB, King DI, Chandler CC. 2009. Effects of management regime on the abundance and nest survival of shrubland birds in wildlife openings in northern New England, USA. Forest Ecology and Management, 258: 1669-1676. DOI: 10.1016/j.foreco.2009.07.025 
Cuervo JJ. 2003. Parental roles and mating system in the black-winged stilt. Canadian Journal of Zoology, 81: 947953. DOI: 10.1139/Z03-082

Cuervo JJ. 2005. Hatching success in Avocet Recurvirostra avosetta and Black-winged Stilt Himantopus himantopus: Capsule Daily survival rate of nests was influenced by laying date and nesting period (laying versus incubation) in both species and by colony size in Black-wi. Bird Study, 52: 166-172. DOI: 10.1080/00063650509461387

Diallo AY. 2012. Sélection des ressources par la Spatule blanche (Platalea leucorodia leucorodia), la Spatule africaine (Platalea alba) et l'échasse blanche (Himantopus himantopus) dans la ZICO (Zone d'importance pour la conservation des oiseaux) des Niayes (Pikine - Séné. Mémoire Master II Biologie animaleEcologie \& Gestion des Ecosystèmes. Université Cheikh Anta Diop, Dakar, p.43.

Dias MP. 2009. Use of Salt Ponds by Wintering Shorebirds throughout the Tidal Cycle. Waterbirds, 32: 531-537. DOI: http://dx.doi.org/10.1675/063.032.0406

Dione M. 2014. Suivi de la population d'Aigrette ardoisée (Egretta ardesiaca) dans les Niayes de Dakar (Sénégal): Technôpole, lac Mbeubeuss et lac Retba. Mémoire Master II Biologie animaleEcologie \& Gestion des Ecosystèmes. Université Cheikh Anta Diop, Dakar, p.30.

Diop N. 2012. Structure et migration d'une population de Goeland d'audouin (Larus audouinii) au Technopole (Dakar,Senegal). Mémoire Master II Biologie animale-Ecologie \& Gestion des Ecosystèmes. Université Cheikh Anta Diop, Dakar, p.44.

Diouf M. 2005. Problématique de conservation de l'écosystème des Niayes de Pikine: l'exemple du Pas-dunes. Mémoire DEA Géographie. Université Cheikh Anta Diop, Dakar p.71.

Espin PMJ, Mather RM, Adams J. 1983. Age and foraging success in Black-winged stilts Himantopus himantopus. Ardea, 71: 225-228.

Faye A. 2010. Diagnostic partiel de la flore et de la végétation des Niayes et du Bassin arachidier au Sénégal: application de méthodes floristique, phytosociologique, ethnobotanique et cartographique. Thèse, Sciences Agronomiques et Ingénierie Biologique. Université Libre de Bruxelles, p.266.

Gadiaga A. 2014. Abondance, répartition et comportement alimentaire du grand cormoran (Phalacrocorax carbo lucidus) au technopole (Dakar - Sénégal). Mémoire Master II Biologie animale Ecologie \& Gestion des Ecosystèmes. Université Cheikh Anta Diop, Dakar, p.30.

Hopkins B, Diop MS. 2011. Birding in Technopole Site of Dakar Senegal, p.5.

Iqbal M, Abdillah A, Nurza A. 2011. Blackwinged Stilt Himantopus himantopus himantopus, a new shorebird for Indonesia. Wader Study Group bull., 117(1).

Issiaka Y, Hamani SH, Illiassou SA, Awaiss A. 2018. Distribution et diversité de la faune aviaire de la ville de Niamey et de sa principale zone humide, le fleuve Niger. Int. J. Biol. Chem. Sci, 12(6): 2626-2643.

DOI: https://dx.doi.org/10.4314/ijbcs.v12i6.13

Lagarde F. 2013. Évaluation du succès de reproduction chez le goéland à bec cerclé de la colonie de l'île Deslauriers. Mémoire de la Maîtrise en Biologie. Université du Québec à Montréal, p.58.

Maheswaran G, Rahmani AR. 2001. Effects of water level changes and wading bird abundance on the foraging behaviour of blacknecked storks Ephippiorhynchus asiaticus in Dudwa National Park, India. Journal of Biosc., 26: 373-382.

Ndiaye O, Diallo A, Matty F, Thiaw A, Fall AD et Guissé A 2012. Caractérisation des sols de la zone des Niayes de Pikine et de Saint Louis (Sénégal). Int. J. Biol. Chem. Sci., 6(1): 519-528. DOI : http://dx.doi.org/10.4314/ijbcs.v6i1.46 
Prasanth S, Dipu S, Vijayan. 2005. Nesting of Black-winged Stilt Himantopus himantopus in Kumarakom, Kerala. Indian bird 1(5).

Rihane A. 2007. Contribution à l'étude de la reproduction de l'Échasse blanche (Himantopus himantopus) dans la daya de Ouled Lahcen (Beni Yakhlef/Mohammedia, Maroc). GoSouth Bulletin, 4: 26-30.

Rofrigues J, Tavares A. 2014. First breeding records of black-winged stilt Himantopus himantopus (Linnaeus, 1758) in the island of Maio. Zoologia Caboverdiana, 5 (1): 61-63.

Roux A. 2008. Le Milan royal en Balagne (Haute-Corse)- Suivi de la reproduction et mesures de conservation-. Master Professionnel "Biologie, Géosciences, Agroressources et Environnement" Spécialité "Ingénierie en Ecologie et en Gestion de la Biodiversité". Université Montpellier II, p.84.

Rueda E, Sherley RB. 2013. First observations of black-winged stilt Himantopus himantopus on Robben island. Ornithological Observations, 4: 24-26.

Sheta BM. 2009. New records of Blackwinged Stilts Himantopus himantopus breeding on the Mediterranean coast of Egypt. Wader Study Group Bull., 116(3).

Stroud DA, Davidson NC, West R, Scott DA,
Haanstra L, Thorup O, Ganter B, Delany S. 2004. Status of migratory wader populations in Africa and Western Eurasia in the 1990s. International Wader Studies, 15: 1-259.

Toral GM, Figuerola J. 2012. Nest success of Black-winged Stilt Himantopus himantopus and Kentish Plover Charadrius alexandrinus in rice fields, southwest Spain. Ardea, 100: 29-36. DOI: $10.5253 / 078.100 .0106$

Touré MN. 2004. Problématique d'aménagement d'une zone humide en milieu urbain: le cas du Technopôle dans les Niayes de Pikine. Mémoire de DEA en Géographie. Université Cheikh Anta Diop, Dakar.

Ueng Y-T, Perng J-J, Wang J-P, Weng J-H, HouP-CL. 2006. Diet of the Black-faced Spoonbill Wintering at Chiku Wetland in Southwestern Taiwan. Waterbirds, 29: 185-190.

DOI: http://dx.doi.org/10.1675/15244695(2006)29[185:DOTBSW]2.0.CO;2

Zean GM, Ahon DB, Koffi BJ-C. 2018. Peuplement avifaunique du Campus Universitaire Jean Lorougnon Guédé, Daloa et sa périphérie (Centre-Ouest de la Côte d'Ivoire). Int. J. Biol. Chem. Sci., 12(6): 2503-2518. DOI: https://dx.doi.org/10.4314/ijbcs.v12i6.4 